\title{
Is Cephalometric Analysis Reliable in Cases with Cleft Lip and Palate?
}

\section{Dudak Damak Yarıkı Olgularda Sefalometrik Analiz Güvenilir mi?}

\author{
Ege Doğan ${ }^{1 *}$, Hasan Çınarcık², Servet Doğan³, Furkan Dindaroğlu \\ 1Private Clinic, İzmir, Turkey. \\ Orcid: 0000-0002-4443-1772 \\ 2Private Clinic, İzmir, Turkey \\ Orcid: 0000-0002-4629-8039 \\ ${ }^{3}$ Ege University, Faculty of Dentistry, Department of Orthodontics, İzmir, Turkey Orcid: 0000-0002-5300-0456 \\ ${ }^{4}$ Ege University, Faculty of Dentistry, Department of Orthodontics, İmir, Turkey Orcid: 0000-0003-4456-3115
}

Atıf/Citation: Doğan, E., Çınarcık, H., Doğan, S. \& Dindaroğlu, F. (2020). Is Cephalometric Analysis Reliable in Cases with Cleft Lip and Palate? Ege Üniversitesi Diş Hekimliği Fakültesi Dergisi, 41(1), 27-37.

\begin{abstract}
Objective: The aim of this study is to test the reliability of the cephalometric measurements made on lateral cephalometric radiographs in unilateral cleft lip and palate patients (UCLP).

Material and Method: The study was carried out on a total of 30 lateral cephalometric images belonging to 15 male patients (mean age: $17.3 \pm 5.2$ years) and 15 female patients (mean age: $16.8 \pm 6.1$ ) who had unilateral complete cleft lip and palate (UCCLP). By utilizing 9 different methods of cephalometric analysis, measurements were made for 94 parameters including skeletal, soft tissue and dental parameters. The measurements were made by 3 researchers (2 inexperienced, 1 experienced) on a computer program; Dolphin Imaging Software 11.7. Paired samples t-test was used to assess intra-observer and interobserver reliability.

Results: In the skeletal measurements, the intra-observer reliability was high in the LAFH (ANS-Me) (mm), in SNA('); Witz $(\mathrm{mm})$; U1-FH ( ${ }^{\circ}$, Nasal Prominence $(\mathrm{mm})$ measurements among the inexperienced researchers $(H 1-H 2)(E 1-E 2)$ and the experienced researcher (S1-S2). The increase in the confidence interval values between two researchers (one experienced, one inexperienced) was high.

Conclusion: Cephalometric analysis is very important in diagnosis and treatment planning in patients with CLP. Particular attention should be paid to marking Na, A, ANS, Subnasal and U1 points which are located in the cleft areas. Reliability limits are especially important in cephalometric measurements on individuals with cleft lip and palate in terms of guiding clinicians.
\end{abstract}

Key words: Cephalometric analysis. Cleft lip and palate. Reliability.

\section{$\ddot{O Z Z}$}

Amaç: Bu çalışmanın amacı, tek taraflı dudak damak yarıklı hastalarda (TDDY) lateral sefalometrik radyografilerde yapılan sefalometrik ölçümlerin güvenilirliğini test etmektir.

Gereç ve Yöntem: Çalışma, TDDY olan 15 erkek hastaya (ortalama yaş: $17.3 \pm 5.2$ yıl) ve 15 kadın hastaya (ortalama yaş: $16.8 \pm 6.1$ ) ait toplam 30 lateral sefalometrik görüntü üzerinde gerçekleştirildi. 9 farklı sefalometrik analiz yöntemi kullanılarak iskelet, yumuşak doku ve dental parametreler dahil toplam 94 parametre için ölçümler yapıldı. Ölçümler; Dolphin Imaging Yazııımı 11.7 kullanılarak 3 araştırmacı (2 deneyimsiz, 1 deneyimli) tarafından yapıldı. Gözlemci içi ve gözlemciler arası güvenilirliği değerlendirmek için paired samples t-testkullanıldı.

Bulgular: İskelet ölçümlerinde, gözlemci içi güvenilirlik LAFH (ANS-Me) (mm), SNA (') Witz (mm); U1-FH ('), nazal çıkıntı (mm) ölçümlerinde deneyimsiz araştırmacılar (H1-H2) (E1-E2) ve deneyimli araştırmacı (S1-S2) arasında yüksek bulunmuştur. Deneyimli ve deneyimsiz araştırııılar arasındaki güven aralı̆̆ı değerlerinde artış yüksek bulunmuştur.

Sonuç: Sefalometrik analiz, dudak damak yarıklı hastalarda tanı ve tedavi planlamasında çok önemlidir. Yarık bölgesinde bulunan Na, A, ANS, Subnazal ve U1 noktalarının işaretlenmesine özellikle dikkat edilmelidir. Sefalometrik ölçümlerde güvenilirlik limitleri özellikle dudak ve damak yarıklı bireylerde rehber oluşturmaktadır ve klinisyenler açısından önem taşımaktadır.

Anahtar kelimeler: Sefalometrik analiz. Dudak ve damak yarıkları. Güvenilirlik. 


\section{INTRODUCTION}

Cleft lip and palate cases are very frequently encountered congenital anomalies that lead to different severities and prevalence rates of deformity among craniofacial anomalies. The treatment of this anomaly, whose etiological factors are not completely known, is a difficult process that is long, comprehensive and requires teamwork. Orthodontic treatment is applied on individuals with cleft lip and palate of different ages and developmental periods starting with the neonatal period 1-4.

Today, 2-dimensional cephalometric imaging methods are still frequently used in planning the diagnosis and treatment of CLP patients. One of the main low-cost methods involves the analysis of conventional 2-dimenaional (2D) lateral cephalometric radiographies. However, there are various difficulties of examining patients with craniofacial deformities and various asymmetries by conventional 2D cephalometric radiographies. This is why $3 \mathrm{D}$ imaging techniques and methods of 3D cephalometric analysis are increasingly being used in the diagnosis of orthodontic anomalies and planning surgical treatment for patients with craniofacial deformities ${ }^{1,5-7}$.

Due to abnormal anatomy in patients with cleft lip and palate (CLP) and craniofacial deformities, maxillary structure distortions are encountered, and difficulties are experienced in the detection of certain anatomical points in cephalometric radiography because of reduced radiopacity in the cleft region, while the reliability of data decreases. It is especially more difficult to determine pairs of anatomic points such as the Gonion and Orbitale points, as well as the anatomic points such as point A or points belonging to the maxillary incisor teeth ${ }^{13,6-8}$. Because of edges and shadows that cannot be easily identified due to lack of clarity in radiography, inaccurate determination of the anatomic points to be used in cephalometric analyses is one of the main reasons of measurement mistakes. The anatomic structures that are found in both sides of the medial sagittal plane form doubled images and may lead to inaccurate determination of asymmetries and some craniofacial deformities. Moreover, the difficulties in the analysis of 2D cephalometric images include magnifications, distortions, errors in positioning the patient, superimpositions and determining some anatomic points ${ }^{3,5-7}$. The Eurocleft studies evaluated the treatment outcome in patients with CLP in different centers.They reported that cephalometric analyses reduced repeatability and reliability, emphasized that radiographic equipment parameters at different centers make standardization difficult and stated that GOSLON scores are more sensitive in the analysis of dental and facial morphologies ${ }^{9}$. In the study by Aras et al. ${ }^{10}$, they compared the anteroposterior projection values of the face by using the Arnett and Gunson Module in unilateral cleft lip and palate (CLP) patients, it was reported that it is difficult to determine the subnasal point.

The purpose of our study is to analyze the intraobserver and inter-observer reliability of measurements that are made on the conventional lateral cephalometric images of patients with unilateral cleft lip and palate (CLP) by additionally considering professional experience.

\section{MATERIAL AND METHOD}

This retrospective study was carried out on the cephalometric images of a total of untreated 30 patients with unilateral complete cleft lip and palate (UCCLP). The lateral cephalometric images to be used in the study were selected from among patients who did have UCCLP. Patients with syndromes accompanying UCCLP, mental retardation or any systemic diseases were excluded from the study. Consequently, the lateral cephalometric images of a total of 30 patients who satisfied the inclusion criteria including 15 male patients (mean age: $17.3 \pm 5.2$ ) and 15 female patients (mean age: $16.8 \pm 6.1$ ) were examined in the study. The procedures followed were in accordance with the ethical standards of the responsible committee on human experimentation and with the Helsinki Declaration of 1975, as revised in 2000.

Before treatment, lateral cephalometric images in the dimensions of $18 \times 24 \mathrm{~cm}$ were obtained by the same technician from all the participants by $77 \mathrm{Kv}, 10 \mathrm{~mA}, 12.5$ seconds of radiation, $152 \mathrm{~cm}$ of object-ray distance and 13 $\mathrm{cm}$ of object-radiography cassette distance (Cranex $\mathrm{D} \AA$, Soredex, Tunsula, Finland). While taking the images, attention was paid to ensure that the patients stood up straight, the Frankfurt horizontal plane was parallel to the ground, the teeth were at centric occlusion, and the lips were in a resting position.

In the study, by taking 9 methods of analysis as a basis: Björk ${ }^{11}$, Downs ${ }^{12}$, Holdaway ${ }^{13}$, Jarabak ${ }^{3}$, McNamara ${ }^{14}$, Ricketts ${ }^{15}$, Jarabak ${ }^{3}$, Steiner ${ }^{16}$, Tweed ${ }^{17}$; totally 85 parameters were measured to include 24 skeletal angular, 18 skeletal linear, 15 dental angular, 15 dental linear, 3 soft tissue angular, and 10 soft tissue linear measurements (Table 1, Figure 1, Figure 2). 
The aforementioned measurements were made by 3 researchers (HC, ED, SD) on the computer program; Dolphin Imaging Software Version 11.7 (Dolphin Imaging, California, USA). The same measurements were repeated by the same researchers after 20 days. While 2 researchers in the study (HC, ED) had 5 years of experience in the field of orthodontics, 1 researcher (SD) had at least 30 years of experience in theirfield.

\section{Statistical analysis:}

The data were analyzed by the SPSS software (Version 22, SPSS Inc, Chicago, Ill). Paired-samples ttest was used to analyze the intra-observer and interobserver reliability levels. The statistically significant level was accepted as $\mathrm{p}<0.05$.

Table 1 - Skeletal, Dental and Soft Tissue Measurements used in thisstudy.

\begin{tabular}{|l|}
\hline \multicolumn{1}{|c|}{ SKELETAL } \\
MEASUREMENTS
\end{tabular}

\begin{tabular}{|c|c|}
\hline $\begin{array}{c}\text { SKELETAL } \\
\text { MEASUREMENTS }\end{array}$ & $\begin{array}{c}\text { SKELETAL } \\
\text { MEASUREMENTS }\end{array}$ \\
\hline Articular Angle (o) & Gonial/Jaw Angle (Ar-Go-Me) (o) \\
\hline Anterior Cranial Base (SN) (mm) & Posterior Cranial Base (S-Ar) (mm) \\
\hline Upper Face Height (N-ANS) (mm) & Lower Face Height (ANS-Gn) (mm) \\
\hline Cranio-Md Base (MP-SN) (o) & Cranio-MxBase/SN-PalatalPlane(o) \\
\hline Mand Plane to Occ Plane (o) & Palatal-Mand Angle (PP-MP) (o) \\
\hline SNB(o) & ANB(o) \\
\hline Facial Angle (FH-NPo) (o) & Convexity (NA- APo) (o) \\
\hline Y-Axis -- Downs (SGn-FH) (o) & Facial Plane to SN (SN-NPog) (o) \\
\hline Jarabak ant. Ratio & MP - SN (o) \\
\hline Y-axis lenght (mm) & Posterior Face Height (SGo) (mm) \\
\hline Y-Axis (SGn-SN) (o) & Midface Length (Co-A) (mm) \\
\hline LAFH (ANS-Me) (mm) & Facial Axis Angle (Ba-Na^Pt-Gn) (o) \\
\hline Maxillary Depth (FH-NA) (o) & Facial Axis- Ricketts (NaBa-PtGn)(o) \\
\hline Pog - NB (mm) & SN - GoGn (o) \\
\hline $\begin{array}{c}\text { DENTAL } \\
\text { MEASUREMENTS }\end{array}$ & $\begin{array}{c}\text { SOFT TISSUE } \\
\text { MEASUREMENTS } \\
\end{array}$ \\
\hline U1-Palatal Plane/MxBase(o) & Lower Lip to H- Line (mm) \\
\hline L1 - MP (LADH) (mm) & Subnasale to H- Line (mm) \\
\hline Occ Plane to FH (o) & Inferior Sulcus to H-Line (mm) \\
\hline U1-Incisor Inclination(U1-APo) (o) & Facial Angle (FH-N’Pg') (o) \\
\hline L1 to A-Po (o) & Superior Sulcus Depth (mm) \\
\hline U1 - NPo (mm) & U-Lip Thickness at A Point (mm) \\
\hline Mand Plane to Occ Plane (o) & U-LipThickness at VerBorder (mm) \\
\hline Molar Relation (mm) & H-Angle (Pg’UL- Pg’Na') (o) \\
\hline Overbite (mm) & Chin Thickness (Pg-Pg’) (mm) \\
\hline U-Incisor Protrusion(U1-APo)(mm) & Nasal Prominence (mm) \\
\hline $\mathrm{U} 1$ - FH (o) & Lower Lip to E- Plane (mm) \\
\hline L1 - NB (mm) & Upper Lip to E- Plane (mm) \\
\hline U1 (labial surface) to NA (mm) & Soft Tissue Convexity (o) \\
\hline $\begin{array}{l}\text { L1 - NB (o) } \\
\text { FMIA (L1-FH) (o) }\end{array}$ & \\
\hline
\end{tabular}




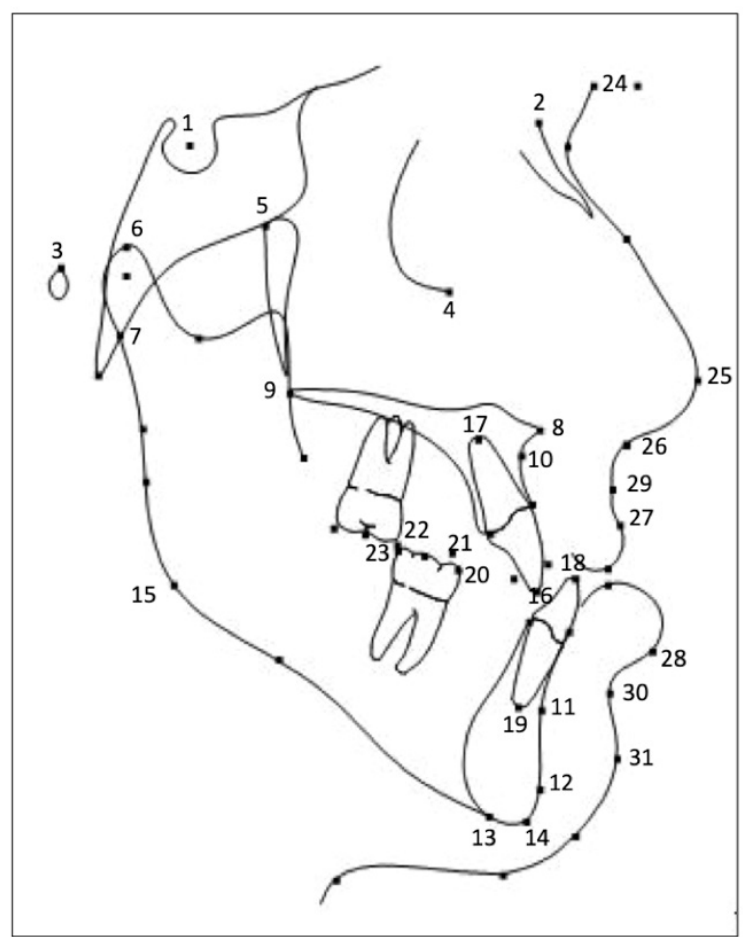

Figure 1 - Cephalometric Points used in thisstudy.

1-Sella (S), 2-Nasion (N), 3-Porion (Po), 4-Orbitale (Or), 5-Pterygoid (Pt), 6-Condylion (Co), 7-Artikulare (Ar), 8-Anterior Nasal Spina (ANS), 9-Posterior Nasal Spina (PNS), 10-Subspinale (A), 11-Supramentale (B), 12-Pogonion (Pg), 13-Menton (Me), 14-Gnathion (Gn), 15-Gonion (Go), 16-Incisor Superior (U1), 17-Apex Superior (As), 18-Incisor İnferior (L1), 19-Apex İnferior (Ai), 20- Mesial contour of lower first molar (Mi) ,21-Mesial tubercle of lower first molar (Mit), 22- Mesial contour of upper first molar (Ms), 23- Mesial tubercle of upper first molar (Mst), 24-Glabella (Gl'), 25-Pronasale (Prn), 26-Subnasale (Sn), 27- Lip superior (Ls), 28- Lip inferior (Li), 29- Sf tissue subspinale (Ss), 30- Soft tissue supramentale (Si), 31-Soft tissue Pogonion (Pg').

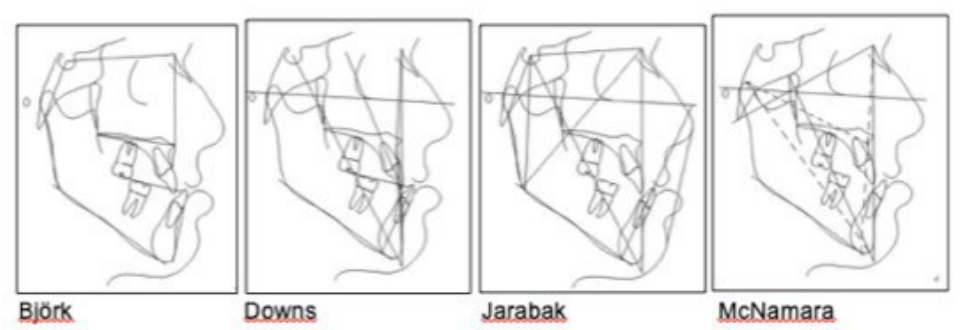

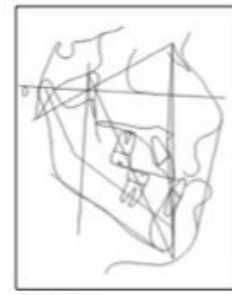

Ricketts

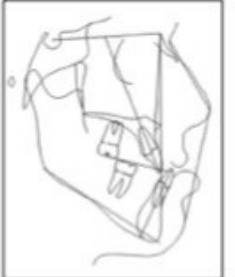

Steiner

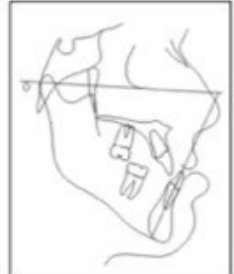

Tweed

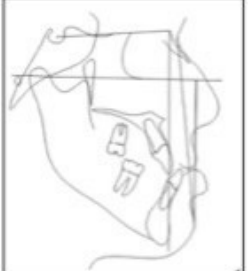

Holdaway

Figure 2 - Cephalometric Planes used in this study. 


\section{RESULTS}

Table 2 shows the data obtained from this study. Differences in SNA $\left(^{\circ}\right)$, Witz (mm), LAFH (ANS$\mathrm{Me})(\mathrm{mm}), \mathrm{U} 1-\mathrm{FH}\left(^{\circ}\right)$, Nasal Prominence $(\mathrm{mm})$ are remarkable.

SNA $\left(^{\circ}\right)$; which is a skeletal angular measurement, in the intra-observer analysis; the mean value was 0.02 and the confidence interval was $-0.66-0.70$ for the $1 \mathrm{st}$ researcher who was inexperienced (H1-H2), respectively 0.03 and $-0.49-0.56$ for the 2nd researcher who was inexperienced (E1-E2) and 0.12 and $-0.94-1.20$ for the 3 rd researcher who was experienced (S1-S2). When the two inexperienced researchers were compared (H1-E1), the mean value was -1.12 and the confidence interval was -1.95 - -0.28 The comparison values between the two observes, one experienced and the other inexperienced (H1-S1), the mean value was -1.50 and the confidence interval was $-3.94-6.94$.

Witz (mm); which is a skeletal linear measurement, in the intra-observer analysis; the mean value was -0.28 and the confidence interval was $-0.93-0.35$ for the 1 st researcher who was inexperienced (H1-H2), respectively 0.45 and -1.07 - 0.17 for the 2nd researcher who was inexperienced (E1-E2) and -0.40 and $-2.32-1.52$ for the 3 rd researcher who was experienced (S1-S2). When the two inexperienced researchers were compared (H1-E1), the mean value was -0.28 and the confidence interval was $-1.12-0.54$ The comparison values between the two observes, one experienced and the other inexperienced (H1-S1), the mean value was -5.50 and the confidence interval was $-1.49-12.49$

LAFH (ANS-Me) (mm); which is a skeletal linear measurements, in the intra-observer analysis; the mean value was 0.38 and the confidence interval was -0.38 - 1.15 for the 1 st researcher who was inexperienced (H1-H2), respectively -1.41 and $-5.64-2.82$ for the 2nd researcher who was inexperienced (E1-E2) and 0.22 and -3.14 - 3.60 for the 3rd researcher who was experienced (S1-S2). When the two inexperienced researchers were compared (H1-E1), the mean value was -2.48 and the confidence interval was $-3.70--1.25$ The comparison values between the two observes, one experienced and the other inexperienced (H1-S1), the mean valuewas -0.81 and the confidence interval was $-5.46-3.83$.

$\mathrm{U} 1-\mathrm{FH}\left({ }^{\circ}\right)$ which is a dental angular measurement, in the intra-observer analysis; the mean value was -0.18 and the confidence interval was $-1.57-1.19$ for the 1 st researcher who was inexperienced $(\mathrm{H} 1-\mathrm{H} 2)$, respectively 0.51 and -1.35 - 2.37 for the 2nd researcher who was inexperienced (E1-E2) and -0.34 and -3.86 - 3.18 for the 3rd researcher who was experienced (S1-S2). When the two inexperienced researchers were compared (H1-E1), the mean value was -1.25 and the confidence interval was -3.69 - 1.19 The comparison values between thetwo observes, one experienced and the other inexperienced (H1-S1), the mean value was 1.58 and the confidence interval was $-14.19-17.36$.

Nasal Prominence (mm) which is a soft tissue measurements, in the intra-observer analysis; values, the mean value was -0.45 and the confidence interval was $-0.87--0.03$ for the 1 st researcher who was inexperienced (H1-H2), respectively -0.97 and $-2.04-0.10$ for the 2nd researcher who was inexperienced (E1-E2) and -0.10 and $-1.19-0.99$ for the 3rd researcher who was experienced (S1-S2). When the two inexperienced researchers were compared (H1-E1), the mean value was -0.83 and the confidence interval was $-1.54--0.12$ The comparison values between the two observes, one experienced and the other inexperienced (H1-S1), the mean valuewas 0.78 and the confidence interval was $-4.15-2.58$.

\section{DISCUSSION}

Conventional 2D lateral cephalometric images, which are some of the most frequently used diagnosis materials in the practice of orthodontics, have advantages such as low costs and low amount of radiation that the patient is exposed to. On the other hand, 2D cephalometric analysis has disadvantages such as magnifications and distortions in 2D radiography images, errors in positioning the patient, superimpositions and difficulties in determining some anatomical points. A conventional cephalometric radiography process reflects the 3dimensional morphologies of craniofacial structures in 2 dimensions. When 3-dimensional structures are imaged in 2 dimensions, not only are the tissues intertwined with each other in the image, but also anatomic formations are exposed to horizontal and vertical positional changes 18-23. There are some difficulties in examining patients with craniofacial deformities such as CLP and various asymmetries through conventional 2D cephalometric 
images ${ }^{23-29}$. With the developments in 3D imaging methods in time, 3D imaging techniques and 3D cephalometric analysis methods are being increasingly used in the diagnosis and treatment planning of orthodontic anomalies in patients with craniofacial deformities ${ }^{29}$.It may be very difficult to determine the anatomic marker points of patients who have craniofacial anomalies such as CLP in conventional 2D images in comparison to normally developed individuals. Today, 2D cephalometric imaging methods are still used routinely in such cases, and treatment plans are made based on the results that are obtained. In the study, while the confidence interval was small and reliability was high between the 1st and 2nd measurements of the inexperienced researchers in all data independently of the region of defect, inter-observer reliability was lower between the two researchers. This difference that was observed was much higher between the inexperienced and experienced researchers.

The ideality of the relationship among skeletal structures, dental structures and soft tissues may vary depending on the cephalometric analysis method that is practiced. In our study, attention was paid to ensure that the number of parameters that were studied was high, and measurements from different regions such as other bones, teeth and soft tissues that form the craniofacial structures were included. This is why our study included parameters that were selected from within different cephalometric analysis.

It was recommended for studies on cephalometric analyses to include as many parameters as possible for the most accurate analysis of craniofacial structures $14,19,23,25,28$. Studies on intra-observer and inter-observer differences reported that reliability was lower in the examination of 2D images. Chien et al. ${ }^{8}$ tested intraobserver and inter-observer reliability for determination of 27 points that were taken as reference on the 3D images and 2D cephalometric images of 10 patients and found that reliability was lower in the 2D images.

It was stated that it is difficult to determine double anatomical points such as Gonion and Orbitale, in addition to the root tips of maxillary and mandibular teeth in cases where the amount of crowding is high in the anterior region $1,2,4,7,8,20,23,26$. In addition to these difficulties in patients with craniofacial deformities such as CLP, it is more difficult to determine points like the point $\mathrm{A}$ and the anatomical marker points on the maxillary teeth because of frequently encountered severe crowding, rotations, supernumerary teeth and abnormal angling situations that are included among bone deformities around the line of the cleft, while there are only a few studies in the literature related to cleft lips and palates ${ }^{1-4,18,23,26}$.

Kumar et al. ${ }^{29}$, compared the conventional lateral cephalograms and 2D lateral cephalometric images obtained from the 3D images of 31 patients. They found a statistically significant difference only in the FMA values. They explained this result by that the points except Menton among the points that form the FMA angle which are Porion, Orbitale, Gonion and Menton may provide doubled images as they are bilateral points, and this is why it is more difficult to detect these.

Liedke et al. ${ }^{30}$, compared the conventional lateral cephalograms and 2D lateral cephalometric images obtained from the 3D images of 30 patients. While 3 of the parameters where differences were observed were related to the angular measurements of maxillary incisor teeth (U1-SN, U1-L1, U1-NA), 3 were skeletal angular parameters including the Gonion point (Gonial angle, PD-MD, SN-GoGn). The researchers explained this difference by that the Gonion point provides a doubled image in some radiography images, and it is difficult to identify the PNS point that forms the palatal plane in patients with CLP. Similarly, in our study, it was thought that the differences in the dental angular measurements were caused by the anomalies in the maxillary anterior teeth of the CLP patients, and it was observed that both the inexperienced and experienced researchers repeatedly made errors in their measurements in these regions. Identification of points on the lateral cephalometric images of especially individuals with CLP is easier by experience.

While the analysis that was carried out only by 2D lateral cephalometric images in planning the diagnosis and treatment of CLP patients was not completely adequate, there were differences between the experienced and inexperienced researchers. While one tomography record to be taken from CLP patients may allow 3D cephalometric analysis, it will be also possible to obtain panoramic, lateral cephalometric, frontal cephalometric and periapical images. This is why we believe that taking tomography records of CLP patients should be a routine procedure in orthodontics. 
․

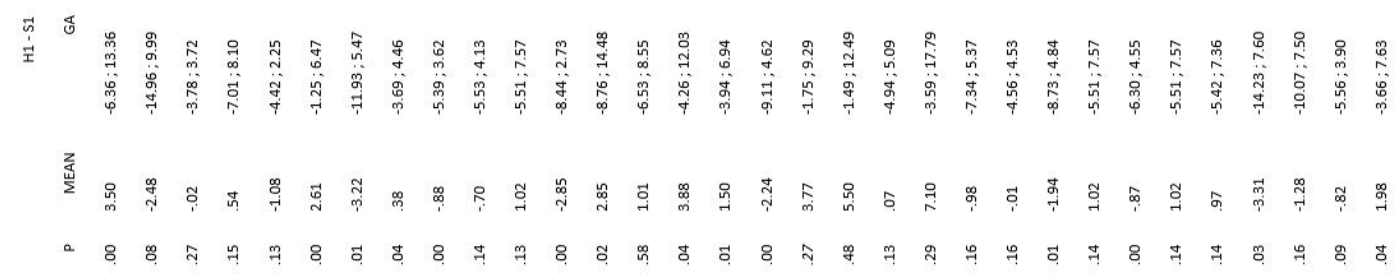

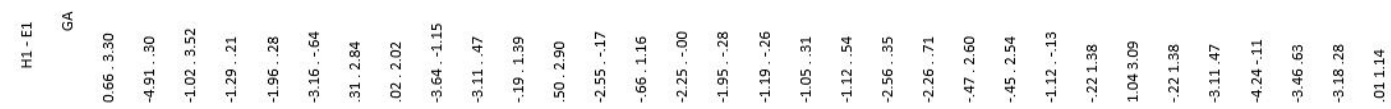

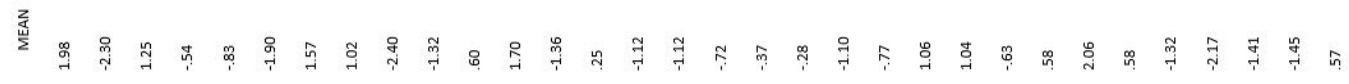

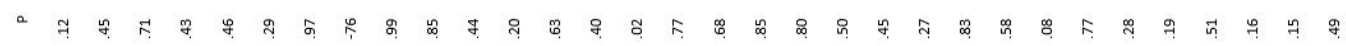

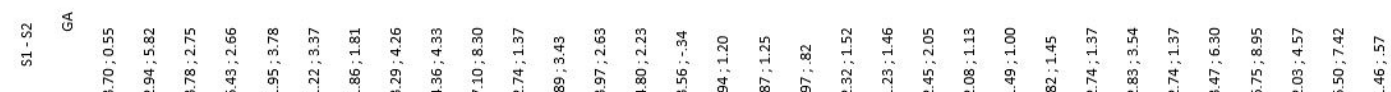

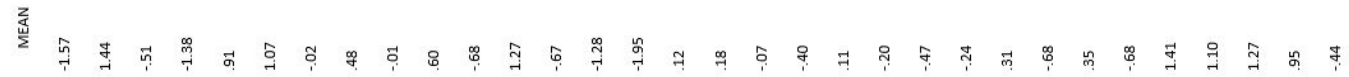

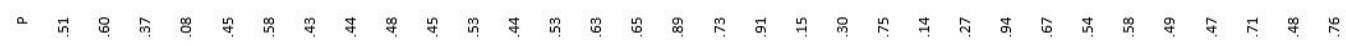

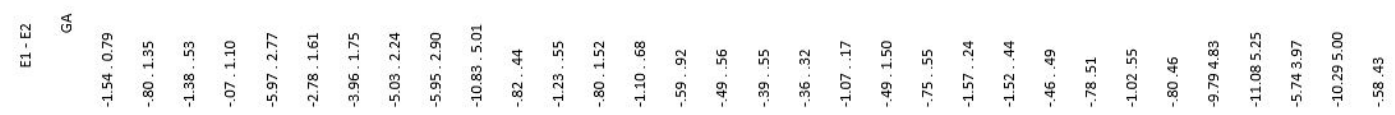

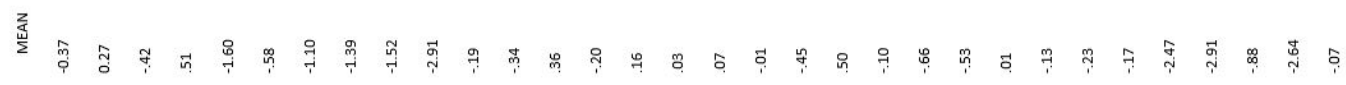

อ ดี

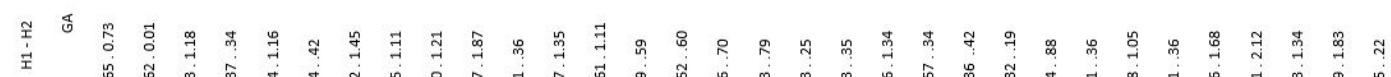

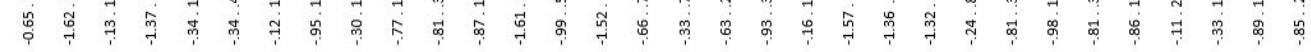

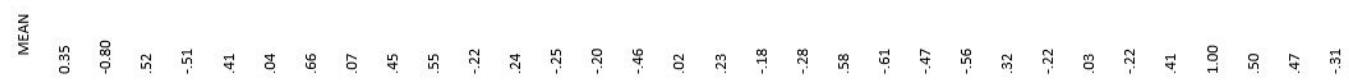

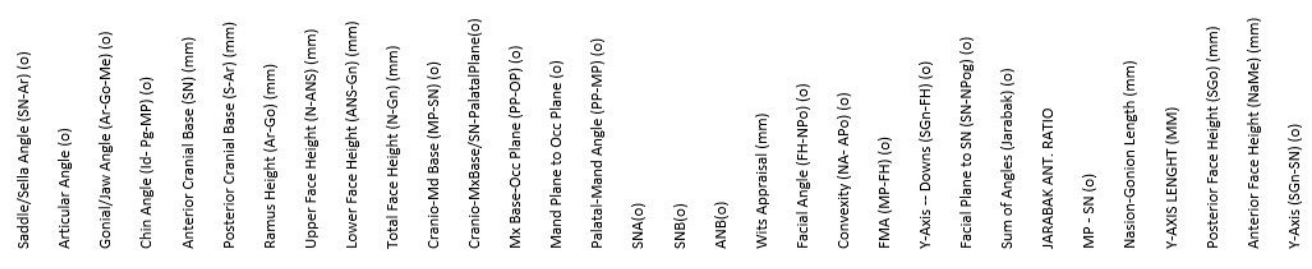

SLNGINGQRSVIN TVLATAYS 


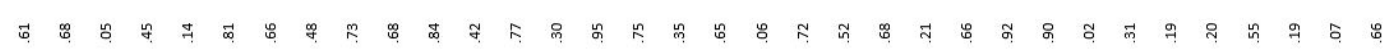

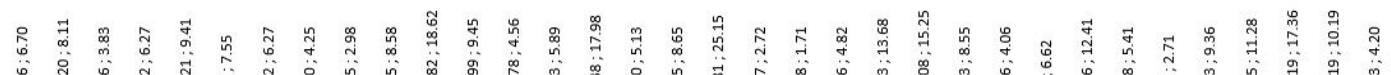

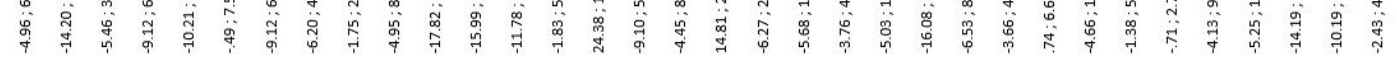

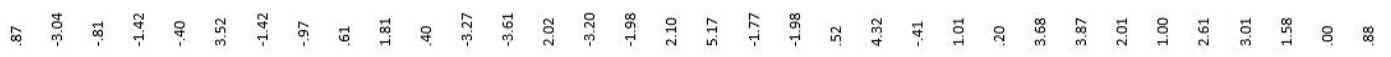

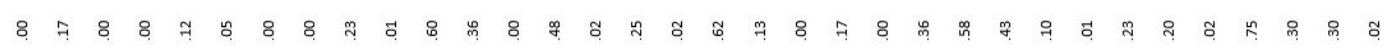

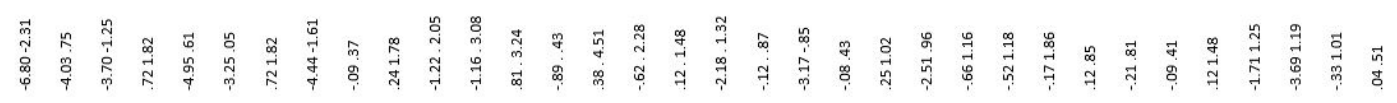

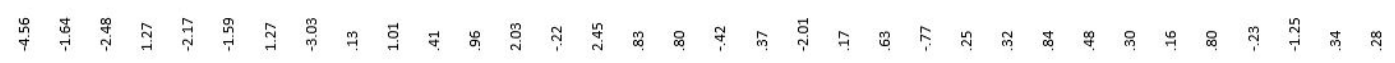
ๆ

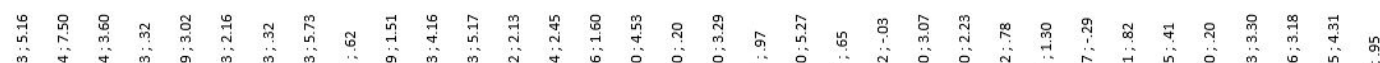

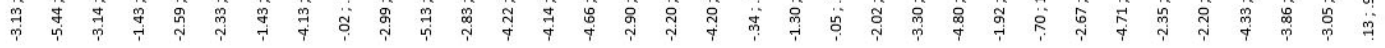

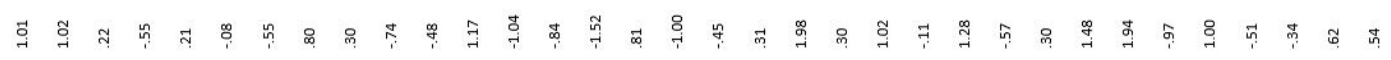

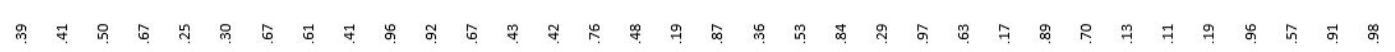

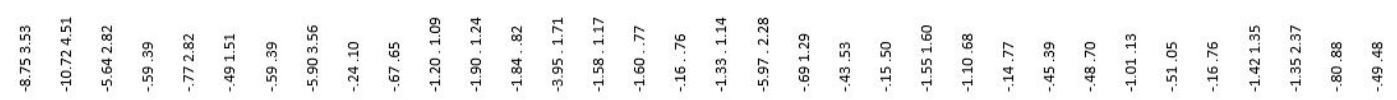

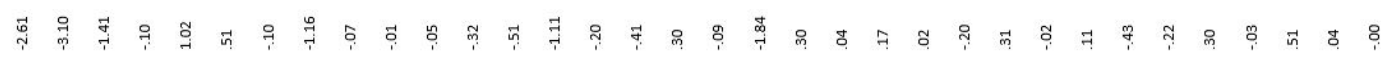

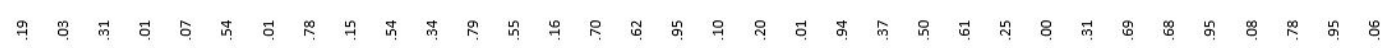

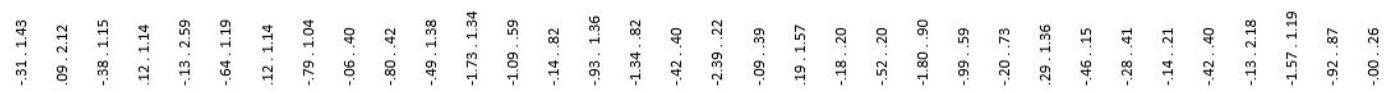

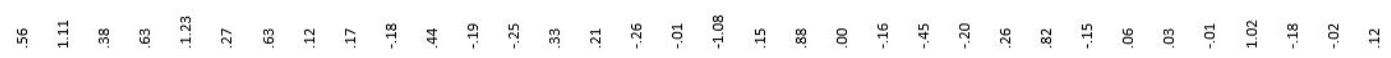

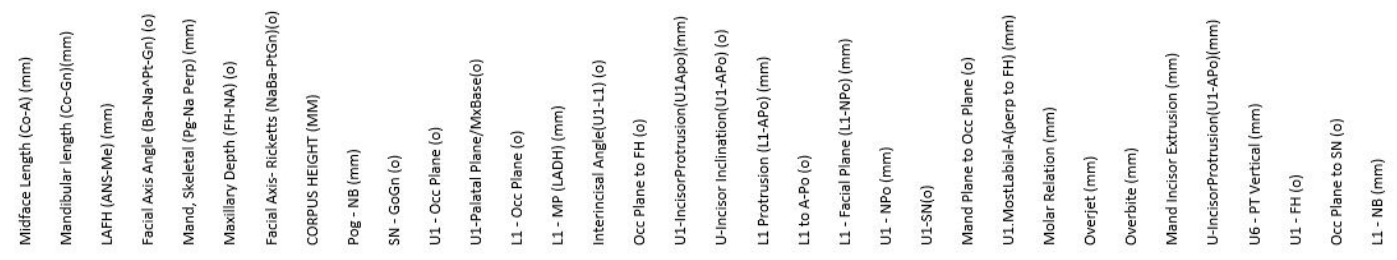

SLNGINGARSVIN TVLNGם 


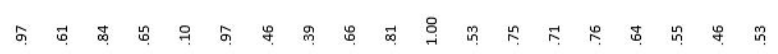

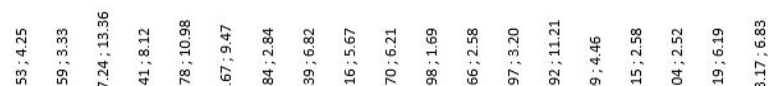

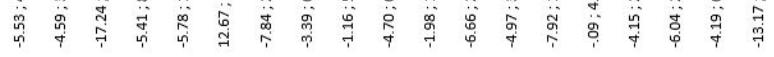

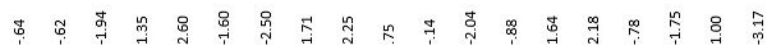

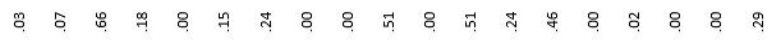

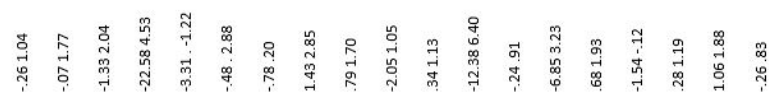

๓

म

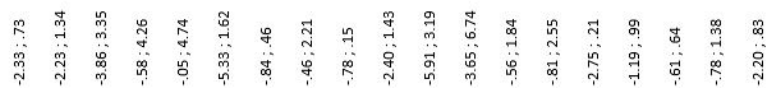

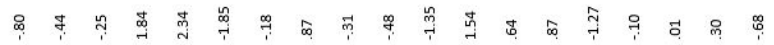

ส ๓

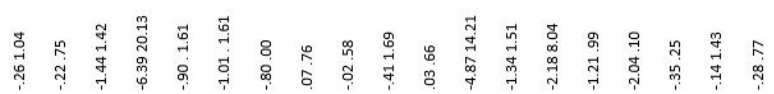

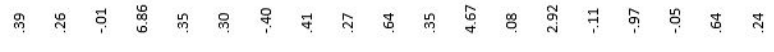

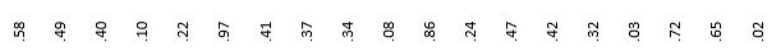

下. ณ

स कु

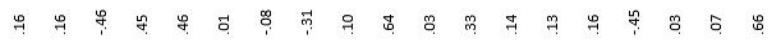

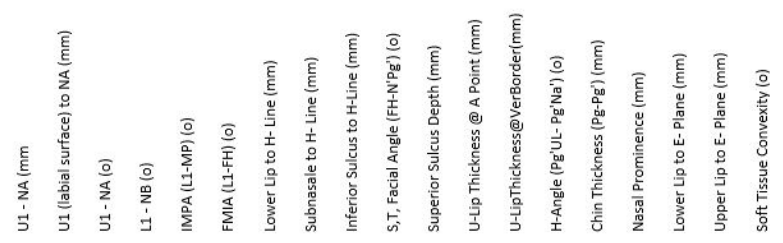

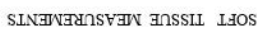




\section{CONCLUSION}

The intra-observer reliability levels of the inexperienced researchers were high in allcephalometric measurements, the inter-observer reliability levels were decreased and this decrease was in clinically significant levels in the analysis of skeletal, dental and soft tissue parameters. The differences between the experienced and inexperienced researchers were high and reliability was low. Reliability values in cephalometric measurements are important in terms of guiding clinicians especially for treating the patients with CLP.

All authors declare that they have no conflict of interest.

There is no financial support /funding source.

This is to verify that we as the authors, do not have financial, economic, professional and/or beneficial interest in a product or service related to this study.

\section{REFERENCES}

1- Kragskov J, Bosch G, Gyldensted C, Sindet-Pedersen S. Comparison of the reliability of craniofacial anatomic landmarks based on cephalometric radiographs and three dimensional CT scans. Cleft Palate Craniofac J. 1997;3(34):111-116.

2- Quintero JC, Trosien A, Hatcher D, Kapila S. Craniofacial imaging in orthodontics: Historical perspective, current status, and future developments. Angle Orthod. 1999;(69):491-506.

3- Rakosi T. Cephalometric radiography. London: Wolfe Medical Publications Ltd. 1982;(7):223.

4-Hagemann K, Vollmer D, Niegel T, Ehmer U, Reuter I. Prospective study on the reproducibility of cephalometric landmarks on conventional and digital lateral headfilms. J Orofac Orthop. 2000;61:91-99.

5- Sam A, Currie K, Oh H, Flores-Mir C, LagravereVich M. Reliability of different three-dimensional cephalometric landmarks in cone-beam computed tomography : A systematic review., Angle Orthod. 2018 Nov 13. doi: 10.2319/042018-302.1.

6- Neelapu BC, Kharbanda OP, Sardana V, Gupta A, Vasamsetti S, Balachandran R, Sardana HK. Automatic localization of three-dimensional cephalometric landmarks on CBCT images by extracting symmetry features of the skull. Dentomaxillofac Radiol. 2018 Feb;47(2):20170054. doi: 10.1259/dmfr.20170054. Epub 2018 Jan 3.

7- Midtgård J, Björk G, Linder-Aronson S. Reproducibility of cephalometric landmarks and errors of measurements of cephalometric cranial distances. Angle Orthod. 1974;(44):56-61.

8- Chien PC, Parks ET, Eraso F, Hartsfield JK, Roberts WE, Ofner S. : Comparison of reliability in anatomical landmark identification using twodimensional digital cephalometrics and threedimensional cone beam computed tomography in vivo. Dentomaxillofac Radiol. 2009 Jul;38:262-73.

9- Mølsted K, Brattstro "m V, Prahl-Andersen B, Shaw WC, Semb G. The Eurocleft study. Intercenter study of treatment outcome in patients with complete uni- lateral cleft lip and palate. Part 3: Dental arch relationships. Cleft Palate Craniofac J. 2004;(42):78-82.

10- Aras I, Altan AB, Doğan S, Yetkiner E.: Evaluation of the Modified True Vertical Line in Unilateral Complete Cleft Lip and Palate Patients.Turkiye Klinikleri J Dental Sci. 2016;(22):92-96.

11- Björk A. The face in profile. Svensk TandlaekareTidskrift, Vol. 40; No. 5B, suppl. Berlingska, Boktrykeriet, Lund, 1947.

12- Downs WB. Analysis of the dento-facial profile. Am J Orthod. 1956;(26):191-212.

13- Holdaway RA. A soft-tissue cephalometric analysis and its use in orthodontic treatment planning. Part II. Am J Orthod. 1984;85(4):279-93.

14- McNamara JA Jr. A method of cephalometric evaluation. Am J Orthod. 1984;(86):449-69.

15- Ricketts RM. Cephalometric Analysis And Synthesis. Angle Orthod. 1961;(7):223.

16- Steiner CC. Cephalometrics for you and me. Am J Orthod. 1953;(39):729-755. 
17- Tweed Ch.: Clinical Orthodontics. The C. V. Mosby Co. St. Louis, U.S.A.; 1966.

18- Drahorádová M, Müllerová Z. Deviations in craniofacial morphology in patients with complete unilateral cleft lip and palate evaluated by Jarabak's analysis. Acta Chir Plast. 1997;39(4):121-124.

19- Chen Y, Hong Y, Wu K, Chen M, Chan H, Chen K. Jaw tariangle analysis: an adjuvan diagnostics. Chin Dent J. 1993;(12):56-70.

20- Gravely JF, Benzies PM. The clinical significance of tracing error in cephalometry. Br J Orthod. 1974;(1):95-101.

21- Mossey PA,Little J, Munger RG, Dixon MJ, Shaw WC. Cleft lip and palate. Lancet. 2009;21:(374):1773-85.

22- Durão AR, Pittayapat P, Rockenbach MI, Olszewski R, Ng S, Ferreira AP, Jacobs R. Validity of 2D lateral cephalometry in orthodontics: a systematic review. Prog Orthod. 2013; 14(1):31.

23- Hofmann E, Fimmers R, Schmid M, Hirschfelder U, Detterbeck A, Hertrich K. Landmarks of the Frankfort horizontal plane:Reliability in a threedimensional Cartesian coordinate system. J Orofac Orthop. 2016;77(5):373-383.

24- Yoon YJ, Kim KS, Hwang MS, Kim HJ, Choi EH, Kim KW. Effect of Head Rotation on Lateral Cephalometric Radiographs. Angle Orthod. 2001;10(71):396-403.
25- Baumrind S, Frantz RC. The reliability of head film measurements 1. Landmark identification. Am J Orthod. 1971;(60):111-127.

26- Midtgård J, Björk G, Linder-Aronson S. Reproducibility of cephalometric landmarks and errors of measurements of cephalometric cranial distances. Angle Orthod.1974;(44):56-61.

27- Stabrun AE, Danielsen K. Precision in cephalometric landmark identification. Eur J Orthod. 1982;(4):185196.

28- David OT, Tuce RA, Munteanu O, Neagu A, Panainte I. Evaluation of the influence of patient positioning on the reliability of lateral cephalometry. Radiol Med. 2017;122(7):520-529.

29- Kumar V, Ludlow J, Soares Cevidanes LH, Mol A. In Vivo Comparison of Conventional and Cone Beam CT Synthesized Cephalograms. Angle Orthod. 2008;9(78):873-879.

30- Liedke GS, Delamare EL, Vizzotto MB, da Silveira HL, Prietsch JR, Dutra V, da Silveira HE. Comparative study between conventional and cone beam CT-synthesized half and total skull cephalograms. Dentomaxillofac Radiol. 2012;(41):136-142. 